\title{
铜陵新桥硫铁矿床中胶状黄铁矿微尺度观察 及其成因探讨
}

谢巧勤 ${ }^{(1)}$ ，陈天虎 ${ }^{(1)}$ (2)，范子良 ${ }^{(1)}$, 徐晓春 ${ }^{(1)}$, 周跃飞 ${ }^{(1)}$ ，石文兵 ${ }^{(3)}$, 谢晶晶 ${ }^{(12)}$

(1) 合肥工业大学资源与环境工程学院, 合肥 230009 ;

(2) 合肥工业大学纳米矿物与环境材料实验室, 合肥 230009 ;

(3) 华东治金地质勘查局 812 地质队, 铜陵 244000

* 联系人, E-mail: chentianhu168@vip.sina.com

收稿日期: 2013-12-17; 接受日期: 2014-05-08; 网络版发表日期: 2014-11-14

国家自然科学基金项目(批准号: 41130206, 41172048 和 41072035)资助

摘要新桥硫铁矿床是铜陵矿集区代表性的层状硫化物矿床, 该矿床主要由层状、似层状矿 体组成, 伴有矽卡岩型、热液脉型矿体. 黄铁矿是层状矿体中主要硫化物矿物, 以胶状、细粒一 中粗粒结构, 块状构造产出, 后期热动力作用使得胶状黄铁矿重结晶为细粒-粗粒黄铁矿, 甚 至相变为磁黄铁矿。本文利用粉晶 $\mathrm{X}$ 射线衍射(XRD)、场发射扫描电镜(FE-SEM)和高分辨透射 电镜(HR-TEM)对新桥硫铁矿床中的胶状黄铁矿物相、形貌、微结构进行研究, 结果发现胶状 黄铁矿基本由黄铁矿组成, 表现为纳米-亚微米粒状、花瓣状和似生物状形态. 粒状黄铁矿以自 形-半自形立方体为主, 球形、短柱状等他形为辅, 粒径大约 10 500 nm; 扫描电镜对胶状黄铁 矿大量观察发现，自形-半自形黄铁矿颗粒粒径大于它形黄铁矿颗粒，显示黄铁矿从小颗粒、不 规则形态向大颗粒、自形晶演化趋势. 花瓣黄铁矿主要由纳米粒级自形-半自形粒状黄铁矿组 成, 花瓣直径介于 5 10 $\mu \mathrm{m}$, 类似于生物成因的草莓黄铁矿. 这些形貌和微结构特征显示胶状 黄铁矿为微生物参与的矿化产物; 新桥硫铁矿中胶状黄铁矿形貌和微结构差异是其就位空间 和演化过程差异所致. 该研究为新桥矿床乃至铜陵矿集区胶状黄铁矿成因和成矿作用提供了 微尺度的矿物学支撑.

关键词

铜陵 胶状黄铁矿 纳米矿物学 微生物 透射电镜
长江中下游地区是我国重要的铁、铜(金、铅、 锌)多金属成矿带, 特别是产于石炭纪地层中的含铜 黄铁矿矿体, 具有举足轻重的地位(王文斌等, 1994). 目前对其成因主要有两种观点: 沉积-叠加改造型(常 印佛等, 1991; 唐永成等, 1998; 郭维民等, 2011a; 侯 增谦等, 2011; 梁建峰等, 2011; 杨爽等, 2012)、岩浆 热液型(毛景文等, 2009). 关于矿床成因争论的焦点
不仅在于石炭纪是否存在沉积成矿作用, 而且涉及 石炭纪沉积成矿作用和燕山期热液成矿作用对矿床 的相对贡献.

黄铁矿是铜陵矿集区石炭纪地层中层状含铜黄 铁矿矿体最主要的硫化物矿物, 该黄铁矿矿体主要 位于石炭纪黄龙组底部, 以层状、似层状和透镜状产 出. 从颗粒粒度角度, 将黄铁矿分为隐晶质胶状黄铁

中文引用格式: 谢巧勤, 陈天虎, 范子良, 等. 2014. 铜陵新桥硫铁矿床中胶状黄铁矿微尺度观察及其成因探讨. 中国科学: 地球科学, 44: 2665-2674

英文引用格式: Xie Q Q, Chen T H, Fan Z L, et al. 2014. Morphological characteristics and genesis of colloform pyrite in Xinqiao Fe-S deposit, Tongling, Anhui Province (in Chinese). Scientia Sinica Terrae, 44: 2665-2674 
矿、显晶质细粒-粗粒黄铁矿. 胶状黄铁矿与粒状黄铁 矿(少量黄铜矿、方铅矿和闪锌矿等)组成赋存于石炭 纪地层中的块状硫化物矿床(杨竹森等, 2004; 任云 生和刘连登, 2006), 与重晶石、菱铁矿和硬石膏等共 同构成铜陵矿集区海西期海底喷流-沉积系统, 为 SEDEX 矿床(即容矿围岩是沉积岩的热水沉积矿床) 有机整体 (曾普胜等, 2004). 由于年代学和地球化学 数据更多的支持成矿作用主要发生在燕山期, 因此 对海西期沉积成矿作用存在与否及其贡献仍存在分 歧(陆建军等, 2008; 毛景文等, 2009; 徐晓春等, 2008a，2008b，2010), 为此长期以来对该块状硫化物 矿床及其中的黄铁矿成因研究备受关注(顾连兴和徐 克勤, 1986; 刘裕庆和刘兆廉, 1987; 蒋少涌等, 2011; 侯增谦等, 2011).

胶状黄铁矿是层状含铜黄铁矿矿体重要组成部 分, 在后期沉积成岩和燕山期岩浆热动力作用下重 结晶为细粒、粗粒黄铁矿, 在温度较高时相变为磁黄 铁矿(顾连兴和徐克勤，1986; 何金祥等，1996; 郭维 民等, 2010, 2011a), 因此胶状黄铁矿在矿集区分布有 限. 虽然前人已经对石炭纪地层中层状胶状黄铁矿 的地质地球化学特征进行广泛研究(杨竹森等, 2004; 李红阳等, 2005; 侯增谦等, 2011; 姚孝德等, 2012), 并获得其沉积成因共识, 然而对胶状黄铁矿形成机 制, 特别是从微尺度的纳米矿物学角度剖析其成因 尚缺少深入研究.

胶状黄铁矿因其颗粒细小, 常规的偏光显微镜 难以观察矿物形貌、微结构, 高分辨电镜具有原子尺 度分辨率, 能够从微尺度揭示胶状黄铁矿组成、超微 结构等成因信息. 为此, 本文以岩浆作用相对较弱、 胶状黄铁矿较为丰富的新桥硫铁矿床为解剖的典型 矿床, 以层状矿体中胶状黄铁矿为主要研究对象, 通 过系统的野外考察、采样、室内手标本观察和高分辨 电镜研究, 探讨新桥胶状黄铁矿成因和形成机制, 以 期对该类型矿床成因和成矿作用提供微尺度的矿物 学支撑.

\section{1 地质概况}

新桥矿田是铜陵矿集区沉积-叠加型典型矿床之 一, 主要由新桥、牛山和莦箕涝三个矿床组成, 新桥 矿床是该矿田最重要矿床. 矿床位于下扬子禇皱带 贵池-马鞍山断褶带中部的舒家店背斜与大成山背斜
和圣冲向斜叠加形成的拗陷部位(图 1). 有关该矿床 年代学、地球化学和成矿作用方面已经积累丰富成果, 然而对矿床形成过程和成矿作用认识仍有较大分歧 (顾连兴和徐克勤, 1986; 谢光华等, 1995; Xu 和 Zhou, 2001; 王彦斌等, 2004a; 李红阳等, 2005; 谢建成等, 2009; 郭维民等, 2011b).

矿区出露地层有中上志留统、上泥盆统五通组, 上石炭统黄龙组和船山组, 中二叠统栖霞组和孤峰 组. 局部地区出露有上二叠统龙潭组和大隆组. 矿区 内与成矿有关的侵入岩为石英二长闪长质的吹头岩 株和牛山岩株, 吹头岩株相对较大, 其出露面积约 $0.5 \mathrm{~km}^{2}$, 同位素年代学表明其形成于燕山期(王彦斌 等, 2004b).

矿体主要以两种产状产出, 第一种是层状、似层 状和透镜状矿体, 胶状黄铁矿主要存在于这种产状 的矿体中, 位于矿体西南端; 第二种是不规则状的接 触-矽卡岩型矿体. 层状矿体是新桥矿床的主矿体, 矿体顶板主要为黄龙组或船山组白云质灰岩和灰岩, 局部为栖霞组, 底板为五通组砂岩, 矿体走向与地层 走向一致, 受地层控制显著. 矿体金属矿物主要为胶 状黄铁矿、粒状黄铁矿, 伴有磁黄铁矿、菱铁矿以及 少量黄铜矿，非金属矿物有石英、白云石、方解石、 石膏等. 层状矿体的矿石主要以纹层状、胶状、球 状-似球状、同心环带状等沉积构造为主, 且具有显著 的地层学分带, 矿石类型自下而上依次为: 含铜黄铁 矿矿石、含铜胶状黄铁矿矿石、黄铁矿矿石、黄铁 矿-菱铁矿矿石(谢光华等, 1995 ; 藏文拴等, 2004; 李 红阳等, 2005). 矽卡岩型矿体是新桥硫铁矿的次要矿 体, 主要产在岩体与围岩接触带, 矿石矿物和脉石矿 物与层状、似层状矿体存在显著差别.

\section{2 样品采集和分析方法}

样品采集于铜陵新桥矿区露天采场和矿井 -300 $\mathrm{m}$ 中段斜巷内. 实验样品为胶状黄铁矿-黄铁矿型矿 石和胶状黄铁矿-菱铁矿型矿石，手标本显示为灰色、 灰黄和黄色，具块状、脉状和浸染状构造(图 2). 经手 标本观察，选择肉眼无法看见黄铁矿颗粒和黄铁矿 脉的胶状黄铁矿样品作为研究对象. 先将块状胶状 黄铁矿样品粗碎，选择位于样品内部、粒径 $1 \mathrm{~cm}$ 左右 的颗粒，然后轻轻敲碎获得无污染的新鲜断面用于 场发射扫描电镜(FE-SEM)分析. 将上一步选择的样 


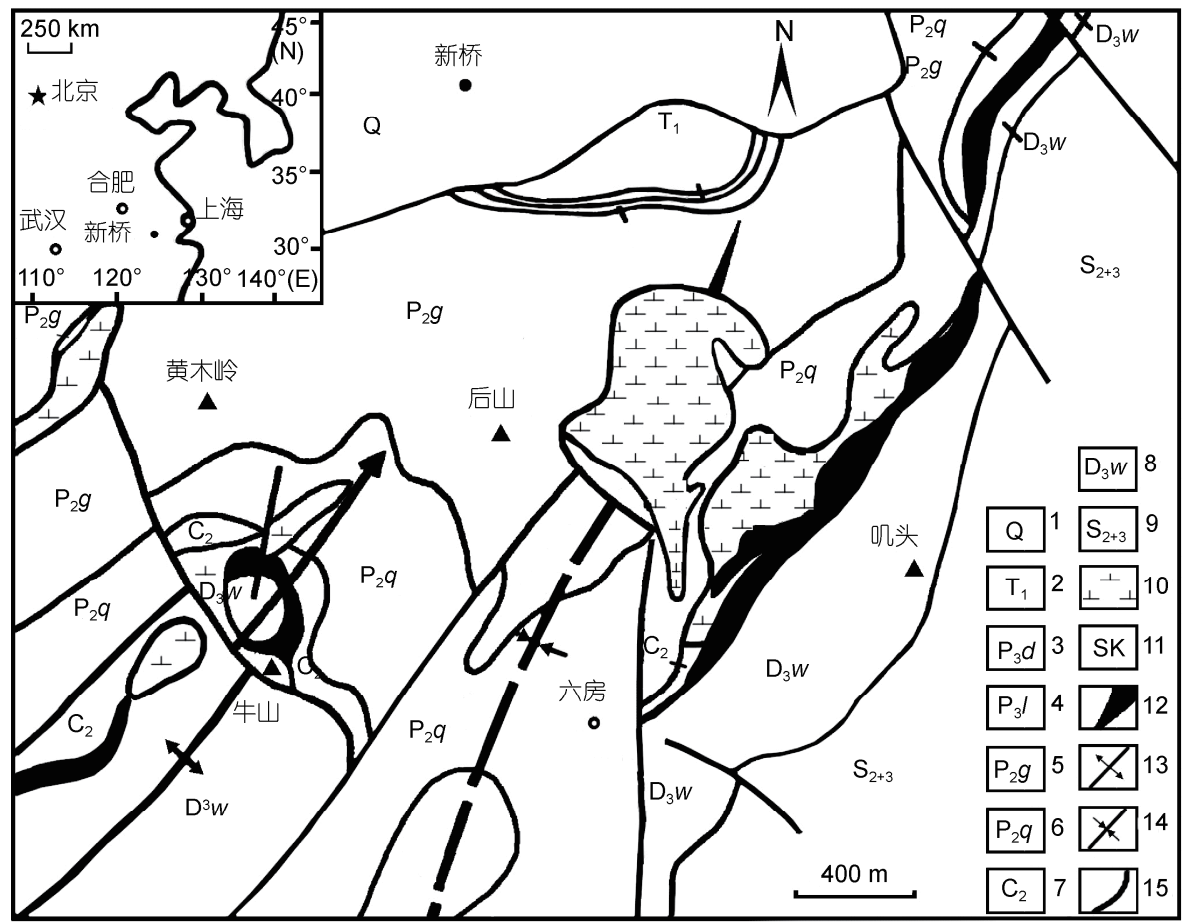

图 1 新桥矿区地质简图

1 , 第四系; 2 , 下三叠统; 3 , 大隆组; 4 , 龙潭组; 5 , 孤峰组; 6 , 栖霞组; 7 , 上石炭统; 8 , 五通组; 9 , 中-上志留系; 10 , 闪长岩体; 11 , 矽卡岩; 12 , 矿体; 13, 大成背斜; 14, 盛冲向斜; 15 , 断层. 据唐永成等(1998)和谢建成等(2009)编绘
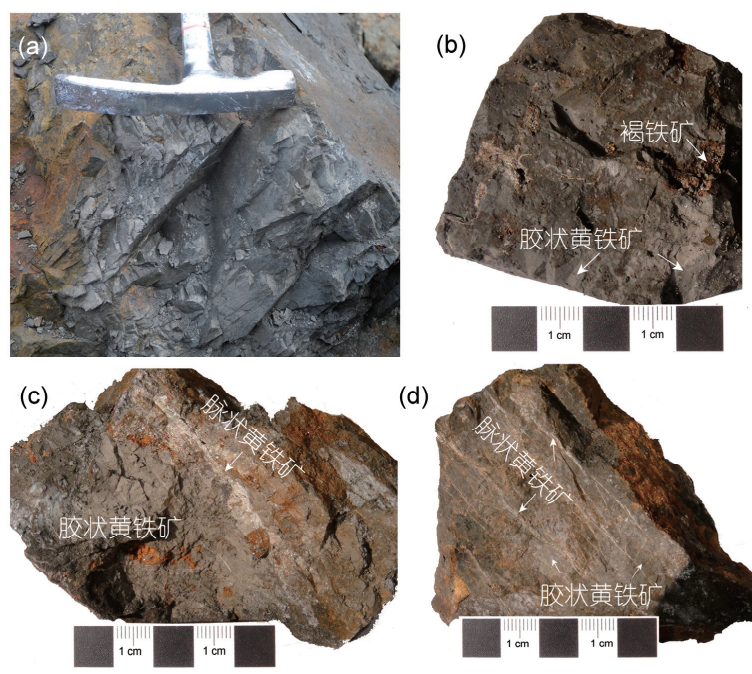

(d)

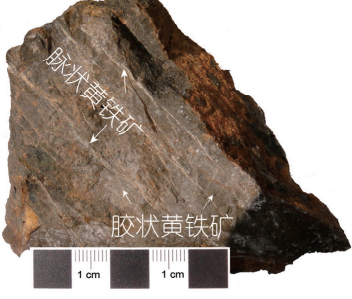

图 2 铜陵新桥矿床不同结构的胶状黄铁矿矿石照片

(a) 矿区原位胶状黄铁矿照片, 矿石矿物完全为胶状黄铁矿, 矿石 为铅灰色, 块状构造, 锤头长 $17 \mathrm{~cm}$; (b) 表面微弱风化氧化的胶状 黄铁矿矿石; (c) 粗粒结构的黄铁矿脉(白色条带)穿切胶状黄铁矿 (浅灰色部分)矿石; (d) 密集、粒状黄铁矿细脉(白色条带)穿切胶状 黄铁矿矿石. 以上照片中表层黄色为黄铁矿风化氧化产物褐铁矿
品破碎过孔径为 $1 \mathrm{~mm}$ 的笁子，然后用蒸馏水清洗 3 次，无水乙醇浸泡清洗 3 次，以去除样品表面或微裂 隙中风化氧化形成的硫酸盐等杂质; 从上一步处理 过样品中取 2 3 $\mathrm{g}$ 样品再研磨过孔径 $75 \mu \mathrm{m}$ 的篮子, 以用于粉晶 $\mathrm{X}$ 射线衍射(XRD)分析. 再从上述用于 $\mathrm{XRD}$ 分析样品中取 $0.1 \mathrm{~g}$ 放于玛瑙针中, 滴入 2 3 滴 无水乙醇, 轻轻研磨 $5 \mathrm{~min}$, 然后取适量制备成用于 透射电镜分析的悬浮液. XRD 和 TEM 分析在合肥工 业大学分析测试中心完成, 仪器为型号分别为 $\mathrm{D} /$ max-RB 和 JEOL2100. FE-SEM 图像及 EDS 分析在中 国科学技术大学合肥微尺度物质科学国家实验室完 成, 仪器型号为 Sirion 200.

\section{3 结果}

\subsection{XRD}

胶状黄铁矿 XRD 分析结果如图 3 所示. 图谱显 示除了非常微弱的针铁矿、石英衍射峰之外, 所有的 衍射峰都归为黄铁矿的衍射峰，表明胶状黄铁矿样 品基本由黄铁矿组成. 至于其中出现微弱的针铁矿 


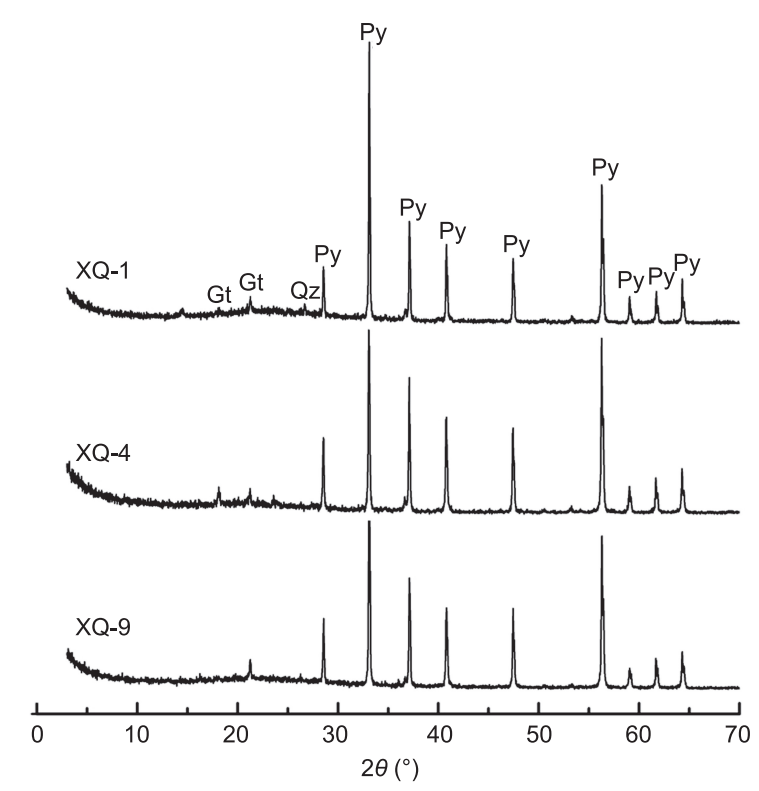

图 3 新桥硫铁矿中胶状黄铁矿 XRD 图谱

Gt, 针铁矿; Qz, 石英; Py, 黄铁矿; XQ-1, 样品编号

特征衍射峰, 归因于胶状黄铁矿微弱的风化氧化. 三 个样品中稳定存在石英的弱衍射峰, 说明有很少量的 石英存在, 其成因和来源尚不清楚. 总体来说, 胶状 黄铁矿样品基本为纯净黄铁矿, 很少其他杂质矿物.

\subsection{FE-SEM}

SEM 显示粒状黄铁矿、花瓣黄铁矿以及具生物 体形貌黄铁矿为胶状黄铁矿主要存在形式(图 4 6). 粒状黄铁矿有自形立方体、短柱状、球型和不规则形 态. 立方体是黄铁矿最主要产出形态, 颗粒粒径相对 均一, 粒径介于 80 500 $\mathrm{nm}$ (图 4(b)). 相比于立方体黄 铁矿颗粒, 他形黄铁矿颗粒以 $100 \mathrm{~nm}$ 左右的纳米颗粒 为主. 大量 SEM 观察显示, 一般自形-半自形立方体 的黄铁矿颗粒粒径大于他形黄铁矿颗粒粒径, 显示了 黄铁矿由他形、小颗粒向自形和大颗粒演化的趋势.

花瓣黄铁矿的花瓣直径介于 $5 \sim 10 \mu \mathrm{m}$ (图 4(a)和 (c)), 花瓣主要由自形-半自形立方体的纳米黄铁矿组 成(图 4(b)和(d)). 虽然组成花瓣的黄铁矿颗粒连生在 一起, 但颗粒边界依然清晰可见, 显示小颗粒演化为 大颗粒. 由花瓣核心向边缘, 黄铁矿自形程度有增加 趋势, 花瓣边缘有的黄铁矿颗粒与其周围基质黄铁 矿颗粒无明显界限. 总体来说, 构成花瓣的黄铁矿自 形程度低于花瓣周围的基质黄铁矿, 可能蕴含二者 形成机制和后期作用的差异. 这种花瓣黄铁矿与生
物成因的草莓黄铁矿粒径分布、形貌极其相似(Wilkin 等, 1996), 暗示它们可能具有相同的成因和形成过程. EDS 分析显示基质黄铁矿和花㦚黄铁矿主要由 $\mathrm{Fe}$ 和 $\mathrm{S}$ 组成, $\mathrm{Fe}$ 和 $\mathrm{S}$ 比例约为 $1: 2$, 与理想黄铁矿化学组 成一致(图 4(e)和(f)).

扫描电镜下具生物体形貌黄铁矿主要有两种, 一种是纤维状(图 5), 另一种为似木桩型(图 6). 这些 形态黄铁矿集合体颗粒一维延长, 长轴方向长度可 达 $500 \mu \mathrm{m}$, 最短约 $1 \mu \mathrm{m}$ (图 5(a)和 6(a)), 在其表面附 着有自形立方体、短柱状黄铁矿颗粒(图 5(c) 和 6(c)), 以及少量片状粘土颗粒和似菌丝体(图 5(b)), 这种菌 丝类似于风化黄铁矿表面的真菌菌丝(陆现彩等, 2011). 高放大倍数下, 这些颗粒似乎被一层薄膜包 裹, 无法看清其中的颗粒形态(图 5(b) 和 6(c)). EDS 分 析显示这些颗粒主要由 $\mathrm{Fe}$ 和 $\mathrm{S}$ 组成, $\mathrm{Fe}: \mathrm{S}$ 比值近似 $1: 2$ (图 5(d)和 6(d)), 元素组成与花瓣黄铁矿完全一致, 显示了它们可能具有相同的成因和形成过程. 所不同 的是木桩型颗粒含有微量的 $\mathrm{Mn}$ (图 6(d)), 这可能是锰 类质同像替代造成. 图 5(d) 和 6(d) 的 EDS 图谱都有 $\mathrm{Au}$ 的特征峰, 源自样品表面喷金(为了增强样品导电性).

\subsection{HR-TEM}

高分辨透射电镜下立方体黄铁矿颗粒清晰可见, 视域中最大颗粒长轴方向长约 $1 \mu \mathrm{m}$, 最小颗粒约 100 $\mathrm{nm}$ 左右(图 7(a)), 与扫描电镜观察结果基本一致. 由 于超声分散没有将黄铁矿颗粒完全分开, 很多黄铁 矿颗粒粘附在一起. 因此, 颗粒中心和边缘因厚度不 同而祄度不同, 一般是颗粒边缘较薄, 祄度较低以灰灰白为主, 颗粒中心或核部较厚祄度高, 颗粒以黑色灰黑为主. 图 7(a)中选区颗粒显示为单颗粒, 而图 7(b)的高分辨图像显示该颗粒由三个直径 10 20 nm 左右的颗粒组成, 并具有黄铁矿 $(022)$ 和 $(0 \overline{2} 2)$ 面网间 距. EDS 分析显示该大颗粒主要由 $\mathrm{Fe}$ 和 $\mathrm{S}$ 组成, $\mathrm{Fe}: \mathrm{S}$ 比值接近 1:2(图 7(d)), 与扫描电镜分析结果一致.

\section{4 讨论}

\section{1 胶状黄铁矿形貌及微结构}

有的文献中将胶状黄铁矿称为胶黄铁矿 (刘裕庆 等, 1984), 本质上来说胶状黄铁矿和胶黄铁矿具有完 全不同的矿物组成和含义. 胶状黄铁矿是指在偏光 显微镜下看不到矿物颗粒大小、形貌, 显示为隐晶质 

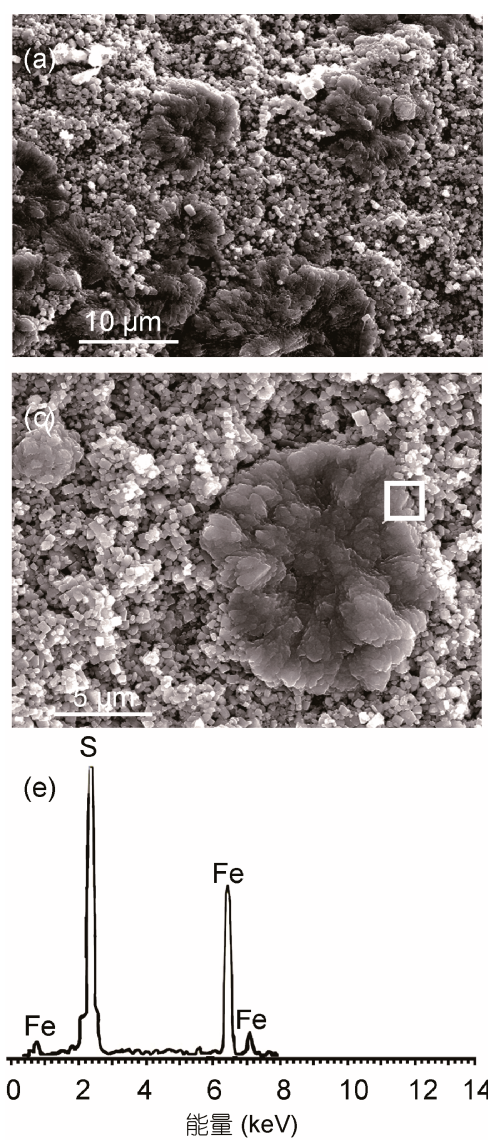
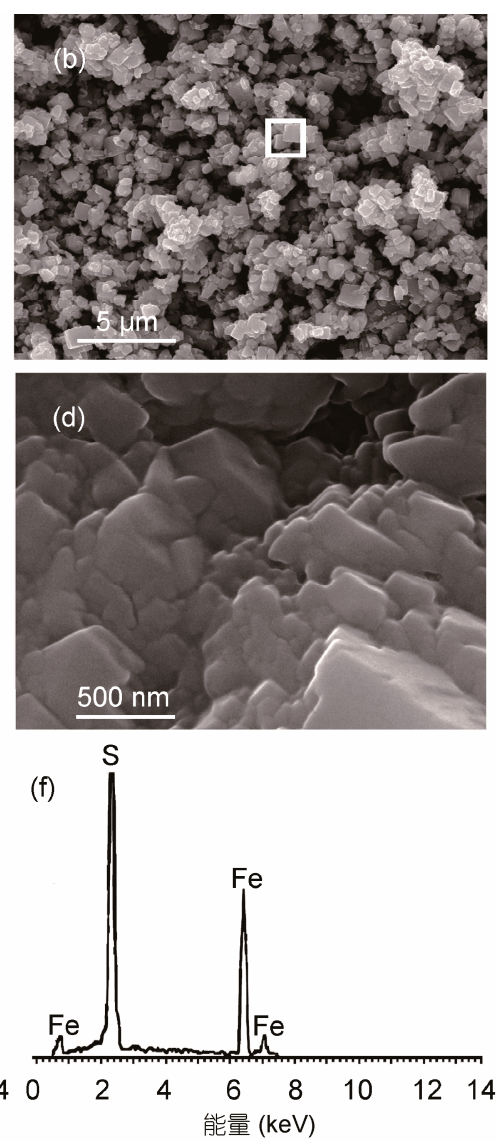

图 4 花瓣型胶状黄铁矿 SEM 照片

(a) 花瓣状胶状黄铁矿在低放大倍数下电镜照片, 显示样品中有很多形态、大小相似的花瓣; (b)为(a)中花瓣周围的粒状黄铁矿局部放大, 将 这些黄铁矿称为基质，也叫基质黄铁矿; (c)为(a)中花瓣局部放大; (d)为(c)局部放大, 显示花瓣有多个自形-半自形小颗粒黄铁矿组成; (e)为(c) 选区 EDS 分析结果; (f)为(d)选区 EDS 分析结果

的黄铁矿，该名称不仅指示了组成矿物，而且具有结 构意义. 而胶黄铁矿是矿物名称, 化学式为 $\mathrm{Fe}_{3} \mathrm{~S}_{4}$, 具 有完整的晶面反射序列(Skinner 等, 1964), 为一种不 稳定具磁性的铁硫化物, 在沉积成岩过程中极易相 变为黄铁矿, 被认为是黄铁矿形成前驱体(Yamaguchi 和 Wada, 1972; Raiswell, 1982; Morse 等, 1987). 胶黄铁矿广泛出现在沉积岩中(Dong 等, 2013), 是沉 积物磁信号重要载体(胡守云等, 2002; Larrasoaña 等, 2007), 与生物关系密切(Mann 等, 1990; Vasiliev 等, 2008; Reinholdsson 等, 2013).

新桥胶状黄铁矿 XRD 图谱显示胶状黄铁矿主要 由黄铁矿组成, 除了微量黄铁矿风化氧化产物针铁 矿和石英外, 几乎不含其他杂质矿物(图 3). 虽然偏 光显微镜下胶状黄铁矿颗粒为隐晶质, 但是在 SEM 下组成胶状黄铁矿的黄铁矿颗粒形貌清晰可见, 颗
粒粒径从约 $10 \mathrm{~nm}$ 的纳米颗粒到亚微米颗粒皆有分 布, 黄铁矿以完全自形立方体为主, 他形为辅, 少见 八面体和五角十二面体. 同时, 自形-半自形立方体 黄铁矿或他形黄铁矿以似生物形貌的集合体形式产 出(图 4 7). 这些形貌和微结构特征暗示胶状黄铁矿 与生物存在密切成因联系. 王道华等(1986)发现下扬 子区中石炭世层状矿体中存在具微生物外形的花瓣 硫化物集合体, 认为矿物似微生物外形的花瓣状、微 球粒结构不仅表明其沉积成因, 而且与海底生物活 动相关. 高分辨电镜对新桥硫铁矿床中胶状黄铁矿 的形貌和微结构研究提供了更多胶状黄铁矿形成与 生物相关的证据.

\section{2 胶状黄铁矿形成机制}

任云生等(2006)认为铜陵矿集区存在两种产状 

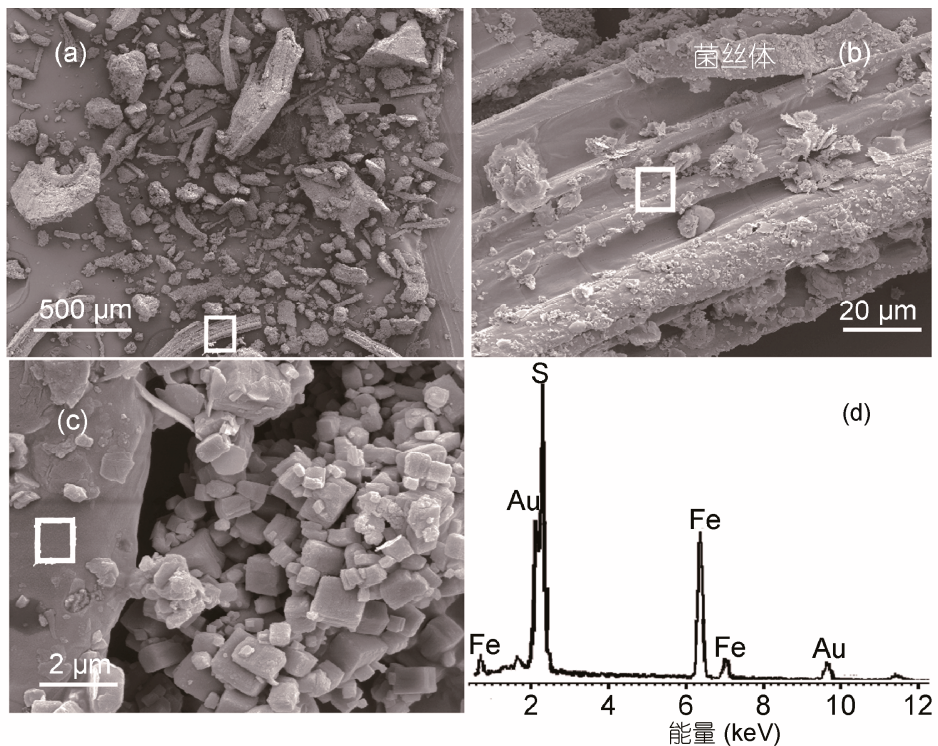

图 5 纤维状胶状黄铁矿 SEM 照片

(a) 纤维状胶状黄铁矿颗粒低放大倍数下照片, 显示样品中有很多纤维状颗粒; (b)为(a)下部中间的纤维状颗粒局部; (c)为(b)局部放大, 显示 胶体颗粒表面仍然分布有很多立方体黄铁矿颗粒; (d)为(c)选区 EDS 分析结果
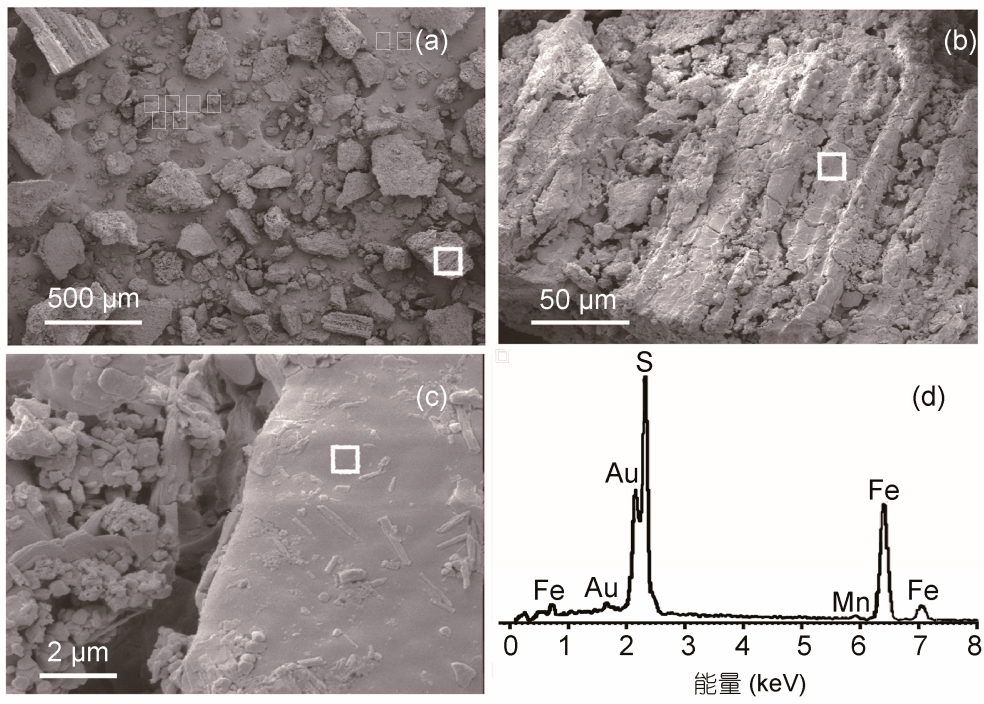

图 6 木桩型胶状黄铁矿颗粒 SEM 照片

(a)木桩型胶状黄铁矿低放大倍数下图片, 显示样品中该形貌的颗粒很多; (b)为(a)右下角木桩型颗粒局部放大, 显示其表面粘附很多细小颗 粒; (c)为(b)选区局部放大; (d)为(c)选区 EDS 分析结果

胶状黄铁矿, 一种是产于石炭纪地层中的层状胶状 黄铁矿; 另一种是脉状胶状黄铁矿, 该胶状黄铁矿主 要产于燕山期岩浆岩体附近, 为高盐度岩浆流体沸 腾作用产物, 属热液成因. 虽然现存的层状胶状黄铁 矿体分布有限, 但是普遍认为是与石炭纪地层同沉 积, 为开放环境下快速沉淀产物 (王文斌等, 1994; 李
文达等，1997)或海底喷流沉积作用形成(顾连兴和徐 克勤, 1986; 蒋少涌等, 2011), 构成石炭纪块状硫化物 矿床, 可能为铜陵矿集区的铜矿床的矿源层或矿胚 层(李文达, 1989; 唐永成等, 1998; Xu 和 Zhou, 2001), 在后期沉积成岩作用和燕山期岩浆作用下, 胶状黄 铁矿重结晶为粗粒黄铁矿, 或相变为磁黄铁矿. 


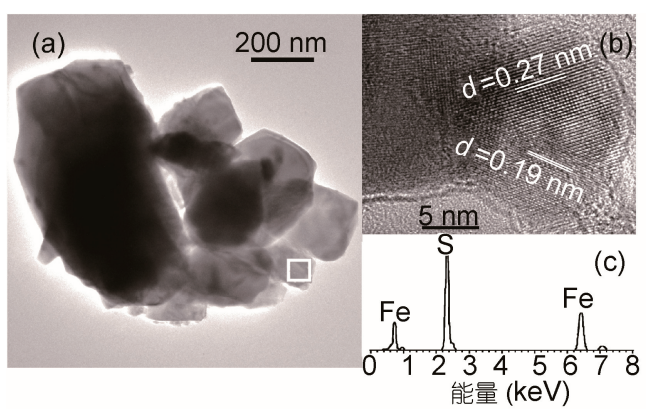

图 7 胶状黄铁矿 HR-TEM 图像

(a) 胶状黄铁矿透射电镜照片; (b)为(a)选区高分辨图像; (c)为(a)选 区 EDS 分析结果

铜陵冬瓜山矿床和新矿矿床的胶状黄铁矿、细 粒-中粗粒黄铁矿硫同位素分析表明, 不同粒径黄铁 矿硫同位素组成没有显著差别, 都为偏离零值不远 的正值(刘裕庆等, 1984; 顾连兴和徐克勤, 1986; 李 红阳等, 2005), 不具典型沉积黄铁矿硫同位素特征, 而类似于深源硫和岩浆硫同位素组成(徐晓春等, 2010). 新桥层状矿体中的胶状黄铁矿铁同位素组成 也显示其为燕山期岩浆热液成矿作用产物 (王跃等, 2013). 周涛发等(2010)利用 LA-ICP-MS 原位测试了 新桥硫铁矿中不同粒径黄铁矿的微量元素, 结果发 现胶状黄铁矿、细粒黄铁矿和粗粒黄铁矿微量元素存 在差别, 并且细粒黄铁矿继承了胶状黄铁矿微量组 成特征, 认为胶状黄铁矿为古生代海底沉积或喷流 沉积成因, 该研究支持顾连兴等(1986)研究结果. 这 些研究从地球化学角度揭示了胶状黄铁矿成因, 但 是尚不能获得完全统一的认识. 为此, 从微尺度纳米 矿物学角度研究胶状黄铁矿显得尤为必要.

SEM 观察显示新桥矿床中的层状胶状黄铁矿颗 粒细小, 粒径相对均一, 富含似生物形貌的黄铁矿, 特别是花瓣黄铁矿, 虽然不是由完全等粒黄铁矿组 成的球型集合体(Rust, 1935), 然而花瓣形貌与草莓 黄铁矿非常相似(Wilkin 等, 1996; Wilkin 和 Barnes, 1997a). 这些特征都表明生物与胶状黄铁矿的密切成 因联系, 为此可以排除层状胶状黄铁矿的岩浆热液 成因. 郭维民等 $(2011 \mathrm{~b})$ 获得了新桥脉状黄铁矿 Re-Os 同位素年龄为 $319 \mathrm{Ma}$, 并认为新桥矿田存在石炭纪 海底喷流沉积成矿年代学证据. 然而该黄铁矿或胶 状黄铁矿是单一无机沉积作用还是生物化学作用尚 需深入研究.

关于生物如何参与黄铁矿或生物黄铁矿形成有
不同观点. Love $(1957,1962)$ 认为草莓黄铁矿即是生物 体内黄铁矿化的化石, 而有的学者认为草莓结构可以 通过前驱体胶黄铁矿磁性吸引形成, 然后胶黄铁矿转 化为黄铁矿 (Sweeney 和 Kaplan, 1973; Goldhaber 和 Kaplan, 1974; Wilkin 和 Arthur, 2001). 大量实验模拟 草莓黄铁矿形成(Sweeney 和 Kaplan, 1973; Rickard, 1975; Luther, 1991; Schoonen 和 Barnes, 1991a), 然而 时至今日, 合成如自然环境下的草莓黄铁矿的实验 寥寥无几(Allan, 2012). Schoonen 等(1991b)认为细菌 还原只是参与硫酸盐还原形成硫化氢, 生物成因的 硫化氢参与黄铁矿形成, 但并不决定黄铁矿形貌. 更多更深入研究认为, 硫酸盐还原菌在黄铁矿形成 过程中是必须的, 它不仅是黄铁矿前驱体硫铁矿的 硫源, 而且影响整个形成过程中黄铁矿的成核速度 (Schoonen, 2004). Wilkin 等(1997a)认为富有机质环 境才能产生还原环境, 由硫酸盐还原菌还原硫酸盐 产生的硫化氢与铁离子反应形成的单硫化铁首先达 到过饱和, 有机质为硫化铁前驱体成核(Grimes 等, 2001)和黄铁矿自生形成提供合适空间 (Ruppert 等, 1992), 从而控制黄铁矿形成和就位. 因此, 沉积黄 铁矿总是与有机质相伴生, 草莓黄铁矿也广泛产于 富有机质的沉积岩(Zhou 和 Jiang, 2009; Wang 等, 2012, 2013) 和现代厌氧环境中 (Wilkin 等, 1997b; Suits 和 Wilkin, 1998), 草莓粒径分布是沉积环境和 氧化还原程度重要指示(Wilkin 和 Barnes, 1997a; Wignall 和 Newton, 1998; Wilkin 和 Arthur, 2001; Wignall 等, 2005; Zhou 和 Jiang, 2009; Wang 等, 2012).

虽然关于生物在黄铁矿形成过程中的作用尚无 一致意见, 但是大量沉积黄铁矿研究对沉积黄铁矿 形成有一些共识, 即微生物(特别是硫酸盐还原菌)参 与硫酸盐还原形成生物成因硫化氢(Ohfuji 和 Rickard, 2005), 硫化氢参与形成黄铁矿, 生物不直接决定矿 物形貌; 黄铁矿不能直接沉淀形成, 而是经过非晶态 硫化铁、有序马基诺矿或胶黄铁矿 (Schoonen 和 Barnes, 1991b; Rickard, 1997; Rickard 和 Luther, 1997; Butler 和 Rickard, 2000; Schoonen, 2004), 这也是现今 沉积黄铁矿广泛认可的形成模型(Allan, 2012). 虽然 黄铁矿形成于还原环境, 但是研究认为其体系中仍 然含有溶解氧, 环境溶解氧能够影响黄铁矿形成和 形貌(Wilkin 和 Barnes, 1997a; Large 等, 1999; Ohfuji 和 Rickard, 2005; 李洪星等, 2012). 李洪星等(2012) 
也认为溶解氧与黄铁矿晶型相关, 溶解氧越高黄铁 矿越趋向于多边形.

SEM 观察新桥胶状黄铁矿以立方体为主, 其次 是球型和他形, 罕见八面体和五角十二面体. 这些都 反映了新桥胶状黄铁矿形成于低溶解氧、富有机质的 还原环境. SEM 下, 基质黄铁矿、花瓣黄铁矿和生物 形貌黄铁矿自形程度差别显著(图 4 6), 基质黄铁矿 自形程度高于生物形态黄铁矿, 这些不仅反映基质黄 铁矿和生物形貌黄铁矿经历了不同的氧化程度, 而且 可能反映它们就位空间和后期演化差异. 特别是生物 体不仅可以作为矿物就位空间而且能够抑制矿物生长 速率, 这些都可能对矿物自形程度产生影响.

李文达等(1989)认为石炭系黄龙组和船山组形 成于全面海侵期, 来自陆源沉积物在陆棚或冒地槽 浅海环境下沉积, 在中石炭世海进层序底部, 同沉积 黄铁矿、碳酸盐及其氧化物. 徐晓春等(2010)对冬瓜 山铜金矿床硫同位素研究认为, 海西期硫酸盐还原 菌参与了区域沉积岩的沉积作用. 蒋少涌等(2011)发 现铜陵冬瓜山矿床中富含微生物的灰泥丘, 纹层状 构造中高碳、硫的黄铁矿层和含细菌结构的矿物层交 替沉积, 这些研究都佐证铜陵矿集区乃至长江中下 游地区赋存于石炭纪地层中的层状含铜黄铁矿体 (即 块状硫化物矿体), 不仅是石炭纪地层沉积产物, 而 且与微生物活动关系密切. 但是该层状矿体是否是 中生代铜矿床成矿的矿源层或是地球化学障尚需进 一步研究.

通过以上综合研究认为, 新桥胶状黄铁矿不仅 与石炭纪地层同沉积, 而且为生物化学作用产物, 特 别是以硫酸盐还原菌为主的微生物关系密切. 微生 物参与新桥胶状黄铁矿矿化可能通过两种机制完成: 第一种是生物体直接就位, 即生物体内矿化, 如图 4 和 6 中胶状黄铁矿颗粒. 在胶状黄铁矿形成的早期, 黄铁矿前驱体(如马基诺矿或胶黄铁矿)在生物体就 位后, 如棘皮动物体腔(李洪星等, 2012), 与周围环 境隔离, 由于环境缺少溶解氧且贫硫, 前驱硫化物生
长和相变缓慢, 导致其形貌和结晶度变化不大, 即使 在沉积埋藏作用下，因生物膜或有机质保护，花瓣黄 铁矿仍然没有充分重结晶, 导致其晶型仍以他形为 主; 第二种是硫酸盐还原菌产生的硫化氢, 与溶液中 铁离子作用直接形成体外矿化的胶状黄铁矿前驱体, 该过程为生物诱导矿化, 这种机制黄铁矿主要以立 方体、球形等自形程度较高的黄铁矿为主. 由于这种 机制黄铁矿形成于开阔沉积环境, 缺少有机质保护, 前驱矿物转化和氧化速度都较快, 因此矿物自形程 度高, 这可能新桥乃至铜陵矿集区胶状黄铁矿主要 形成机制. 结合区域演化概括新桥硫铁矿床层状矿 体中铁硫化物形成和演化趋势为: 石炭纪生物化学 沉积作用(320 Ma 左右)、沉积后成岩作用(介于石炭 纪后-燕山期岩浆作用前，即 320 140 Ma)和燕山期 岩浆热作用 (时间大约为 $140 \mathrm{Ma}$ ); 铁硫化物矿物形 成和演化时序为: 前驱硫化物(可能是有序马基诺矿 或胶黄铁矿)-胶状黄铁矿-纳米立方体黄铁矿-微米粗 粒黄铁矿-单斜磁黄铁矿-六方磁黄铁矿.

\section{5 结论}

通过 XRD, SEM 和 TEM 对铜陵新桥胶状黄铁矿 形貌、微结构观察研究, 得到以下结论.

(1) 新桥胶状黄铁矿主要由纳米-亚微米黄铁矿 组成, 该黄铁矿与常规的显晶质粗粒黄铁矿在矿物 学特征上无显著差别.

（2）胶状黄铁矿以粒状、花瓣状和似生物状产出, 粒状黄铁矿以自形-半自形立方体为主, 球形、短柱状 和他形为辅, 其粒径大多为纳米粒级.

(3) 胶状黄铁矿中含有生物残体及与生物有关 的花瓣黄铁矿、似生物形貌黄铁矿, 这些形貌和微结 构特征不仅蕴含其沉积成因信息，而且表明生物对 其形成的制约和控制作用.

(4) 胶状黄铁矿为石炭纪地层同沉积过程中生 物化学作用产物, 为生物诱导矿化机制.

致谢感谢合肥工业大学分析测试中心透射电镜室汪洋老师、中国科学技术大学合肥微尺度物质科学国家实验室扫 描电镜室李明和付圣权老师在样品分析测试过程中提供的大力帮助, 特别感谢审稿人对稿件提出的建设性修 改意见。

\section{参考文献}

曾普胜, 蒙义峰, 杨竹森, 等. 2004. 安徽铜陵矿集区与块状硫化物矿床有关的热水沉积岩. 矿床地质, 23: 334-343 
常印佛, 刘湘培, 吴言昌. 1991. 长江中下游铜铁成矿带. 北京：地质出版社. 8-385

顾连兴, 徐克勤. 1986. 论长江中下游石炭纪海底块状硫化物矿床. 地质学报, 62: 176-188

郭维民, 陆建军, 蒋少涌, 等. $2011 \mathrm{~b}$. 安徽铜陵新桥矿床下盘矿化中黄铁矿 Re-Os 同位素定年: 海底喷流沉积成矿的年代学证据. 中国科

学: 地球科学, 56: 3023-3028

郭维民, 陆建军, 章荣清, 等. 2010. 安徽铜陵冬瓜山矿床中磁黄铁矿矿石结构特征及其成因意义. 矿床地质, 29: 405-414

郭维民, 陆建军, 章荣清, 等. 2011a. 安徽铜陵冬瓜山铜矿床的叠加改造成矿机制: 来自矿石结构的证据. 地质学报, 85: 1223-1232

何金祥, 徐克勤, 顾连兴. 1996. 对马山、大宝山变质成因磁黄铁矿不同组成结构的认识. 地球科学, 21: 305-310

侯增谦, 杨竹森, 吕庆田, 等. 2011. 安徽铜陵冬瓜山大型铜矿: 海底喷流-沉积与矽卡岩化叠加复合成矿过程. 地质学报, 85: 659-686

胡守云, Appel E, Hoffmann V, 等. 2002. 湖泊沉积物中胶黄铁矿的鉴定及其磁学意义. 中国科学 D 辑: 地球科学, 32: 234-238

蒋少涌, 清峰, 杨水源, 等. 2011. 长江中下游成矿带铜多金属矿床中灰泥丘的发现及其意义一一以武山和冬瓜山铜矿为例. 地质学报, 85: 744-756

李红阳, 李英杰, 侯增谦, 等. 2005. 安徽新桥块状硫化物矿床地球化学特征. 地质科学, 40: 337-345

李洪星, 陆现彩, 边立曾, 等. 2012. 草莓黄铁矿微晶形态和成分的地质意义一以栖霞组含泥灰岩为例. 矿物学报, 32: 443-448

李文达, 王文斌, 范洪源, 等. 1997. 长江中下游铜(金)矿床密集区形成条件和超大型矿床存在的可能性. 火山地质与矿产, 20: 1-131

李文达. 1989. 论扬子型铜矿床及其成因. 中国地质科学院南京地质矿产研究所所刊, 10: 1-14

梁建峰, 徐晓春, 肖秋香, 等. 2011. 安徽铜陵冬瓜山金矿床黄铁矿微量元素原位 LA-ICP-MS 分析及其成矿意义. 矿物学报(增刊):

1011-1012

刘裕庆, 刘兆廉, 杨成兴. 1984. 铜陵地区冬瓜山铜矿的稳定同位素研究. 中国地质科学院矿床地质研究所所刊, 11:1-31

刘裕庆, 刘兆廉. 1987. 安徽铜陵地区石炭系地层中层状铜铁硫矿床的铅同位素研究. 中国地质科学院矿床地质研究所所刊, 2: 143-152

陆建军, 郭维民, 陈卫锋, 等. 2008. 安徽铜陵冬瓜山铜(金)矿床成矿模式. 岩石学报, 24: 1857-1864

陆现彩, 屠博文, 朱婷婷, 等. 2011. 风化过程中矿物表面微生物附着现象及意义. 高校地质学报, 17: 21-28

毛景文, 邵拥军, 谢桂青, 等. 2009. 长江中下游成矿带铜陵矿集区铜多金属矿床模型. 矿床地质, 28: 109-119

任云生, 刘连登. 2006. 铜陵地区热液成因胶状黄铁矿及其成矿意义. 矿床地质, 25: 95-98

唐永成，吴言昌，储国正，等. 1998. 安徽沿江地区铜金多金属矿床地质. 北京：地质出版社. 1-351

王道华，傅德金金，吴履秀，等. 1986. 下扬子区中石炭世“沉积-海底喷出沉积”层状铜(多金属)矿床稳定同位素的特征. 中国地质科学院地 质矿产研究所所刊, 7: 1-25

王文斌, 李文达, 董平, 等. 1994. 论长江中下游地区含铜黄铁矿型矿床成因. 火山地质与矿产, 15: 25-34

王彦斌, 刘敦一, 蒙义峰, 等. 2004b. 安徽铜陵新桥铜-硫-铁-金矿床中石英闪长岩和辉绿岩锆石 SHRIMP 年代学及其意义. 中国地质, 31 : $169-173$

王彦斌, 唐索寒, 王进辉, 等. 2004a. 安徽新桥铜金矿床黄铁矿 $\mathrm{Rb} / \mathrm{Sr}$ 同位素年龄数据. 地质论评, 5: 538-542

王跃, 朱祥坤, 程彦博, 等. 2013. 安徽新桥矿床矿相学与 $\mathrm{Fe}$ 同位素特征及其对矿场成因的制约. 吉林大学学报(地球科学版), 43: $1787-1798$

谢光华, 王文斌, 李文达. 1995. 安徽新桥铜硫矿床成矿时代及成矿物质来源. 火山地质与矿产, 16: 101-107

谢建成, 杨晓勇, 杜建国, 等. 2009. 安徽铜陵新桥 $\mathrm{Cu}-\mathrm{Au}-\mathrm{Fe}-\mathrm{S}$ 黄铁矿 Re-Os 定年及成矿意义. 地质科学, 44: 183-192

徐晓春, 陆三明, 谢巧勤, 等. 2008a. 安徽铜陵狮子山矿田岩浆岩锆石 SHRIMP 定年及其成因意义. 地质学报, 82: 500-509

徐晓春, 陆三明, 谢巧勤, 等. 2008b. 安徽铜陵冬瓜山铜金矿床流体包裹体微量元素地球化学特征及其地质意义. 岩石学报, 24 : 1865-1874

徐晓春, 尹涛, 楼金伟, 等. 2010. 铜陵冬瓜山层控矽卡岩型铜金矿床的成因机制: 硫同位素制约. 岩石学报, 26: 2739-2750

杨爽, 杜杨松, 曹毅, 等. 2012. 安徽铜陵冬瓜山层控矽卡岩铜矿床形成过程一一来自磁黄铁矿的证据. 现代地质, 26: 235-242

杨竹森, 侯增谦, 蒙义峰, 等. 2004. 安徽铜陵矿集区海西期喷流沉积流体系统时空结构. 矿床地质, 23: 281-297

姚孝德，杜建国，许卫，等. 2012. 安徽省铜陵矿集区区域成矿模式. 合肥工业大学学报(自然科学版), 35: 965-976

藏文栓, 吴金国, 张达, 等. 2004. 铜陵新桥矿田地质地球化学特征及成因浅析. 大地构造与成矿学, 2: 187-193

周涛发, 张乐骏, 袁峰, 等. 2010. 安徽铜陵新桥 Cu-Au-S 矿床黄铁矿微量元素 LA-ICP-MS 原位测定及其对矿床成因的制约. 地学前缘, 17: 306-319

Allan K. 2012. Minor element distribution in iron disulfides in coal: A geochemical review. Int J Coal Geol, 94: 32-43

Butler I D, Rickard D. 2000. Framboidal pyrite formation via the oxidation of iron (II) monosulfide by hydrogen sulfide. Geochim Cosmochim Acta, 63: 247-275

Dong J, Zhang S H, Jiang G Q, et al. 2013.Greigite from carbonate concretions of the Ediacaran doushantuo formation in South China and its environmental implications. Precambrian Res, 225: 77-85

Goldhaber M B, Kaplan I R. 1974. The sulfur cycle. In: Goldberg E, ed. The Sea, 5. Chichester: Wiley. 569-655

Grimes S T, Brock F, Rickard D, et al. 2001. Understanding fossilization: Experimental pyritization of plants. Geology, 29: 123-126 
Large D J, Sawtowicz Z, Spratt J. 1999. A cobaltite-framboidal pyrite association from the kupferschiefer: Possible implications for trace element behaviour during the earliest stages of diagenesis. Mineral Mag, 63: 353-361

Larrasoaña J C, Roberts A P, Musgrave R J, et al. 2007. Diagenetic formation of greigite and pyrrhotite in gas hydrate marine sedimentary systems. Earth Planet Sci Lett, 261: 350-366

Love L G. 1962. Biogenic primary sulphide of the Permian kupferschiefer and marl slate. Econ Geol, 57: 350-366

Love L G. 1957. Microorganisms and the presence of syngenetic pyrite. Quart J Geol Soc London, 113: 429-440

Luther G W. 1991. Pyrite synthesis via polysulfide compounds. Geochim Cosmochim Acta, 55: 2839-2849

Mann S, Nicholas H C Sparks, Frankel R B, et al. 1990. Biomineralization of ferromagnetic greigite $\left(\mathrm{Fe}_{3} \mathrm{~S}_{4}\right)$ and iron pyrite $\left(\mathrm{FeS}_{2}\right)$ in a magnetotactic bacterium. Nature, 343: 258-261

Morse J W, Millero F J, Comwell J C, et al. 1987. The chemistry of the hydrogen sulfide and iron sulfide systemsin natural waters. Earth-Sci Rev, 24: $1-42$

Ohfuji H, Rickard D. 2005. Experimental synthesis of framboids-A review. Earth-Sci Rev, 71: 147-170

Raiswell R. 1982. Pyrite texture, isotopic composition, and availabilityof Fe. Am J Sci, 282: 1244-1263

Reinholdsson M, Snowball I, Zillén L, et al. 2013. Magnetic enhancement of Baltic Sea sapropels by greigite magnetofossils. Earth Planet Sci Lett, 366: 137-150

Rickard D, Luther G W. 1997. Kinetics of pyrite formation by the $\mathrm{H}_{2} \mathrm{~S}$ oxidation of iron (II) monosulfide in aqueous solutions between 25 and $125^{\circ} \mathrm{C}$ : The mechanism. Geochim Cosmochim Acta, 61: 135-147

Rickard D T. 1975. Kinetics and mechanism of pyrite formationat low temperatures. Am J Sci, 275: 636-652

Rickard D. 1997. Kinetics of pyrite formation by the $\mathrm{H}_{2} \mathrm{~S}$ oxidation of iron (II) monosulfide in aqueous solutions between 25 and $125^{\circ} \mathrm{C}$ : The rate equation. Geochim Cosmochim Acta, 61: 115-134

Ruppert L F, Minkin J A, Mc Gee J J, et al. 1992. An occurrence of arsenic-bearing pyrite in the Upper Freeport coal bed, west-central Pennsylvania. Energ Fuel, 6: 120-125

Rust G W. 1935. Colloidal primary copper ores at Cornwall mines, southeastern Missouri. J Geol, 43: 398-426

Schoonen M A A, Barnes H L. 1991a. Reactions formingpyrite and marcasite from solution: II. Via FeS precursors below $100^{\circ} \mathrm{C}$. Geochim Cosmochim Acta, 55: 1505-1514

Schoonen M A A. 2004. Mechanisms of sedimentary pyrite formation. In: Amend J P, Edwards K R, Lyons T W, eds. Sulfur Biogeochemistry. Geol Soc Amer Spec Pap, 379: 117-134

Schoonen M A A. Barnes H L. 1991b. Reactions forming pyrite and marcasite from solution: I. Nucleation of $\mathrm{FeS}_{2}$ below $100^{\circ} \mathrm{C}$. Geochim Cosmochim Acta, 55: 1495-1504

Skinner B J, Erd R C, Grimaldi F S. 1964. Greigite, the thio-spinel of iron: A new mineral. Am Mineral, 49: 543-555

Suits N S, Wilkin R T. 1998. Pyrite formation in the water column and sediments of a meromictic lake. Geology, 26: 1099-1102

Sweeney R E, Kaplan I R. 1973. Pyrite framboid formation: Laboratory synthesis and marine sediments. Econ Geol, 68: 618-634

Vasiliev I, Franke C, Meeldijk J D, et al. 2008. Putative greigite magnetofossils from the Pliocene epoch. Nature, 82-786

Wang L, Shi X Y, Jiang G Q. 2012. Pyrite morphology and redox fluctuations recorded in the Ediacaran doushantuo formation. Paleogeogr Paleoclimatol Paleoecol, 333: 218-227

Wang P K, Huang Y J, Wang C S, et al. 2013. Pyrite morphology in the first member of the Late Cretaceous Qingshankou formation, Songliao Basin, Northeast China. Paleogeogr Paleoclimatol Paleoecol, 385: 125-136

Wignall P B, Newton R, Brookfield M E. 2005. Pyrite framboid evidence for oxygenpoor deposition during the Permin-Triassic crisis in Kashmir. Paleogeogr Paleoclimatol Paleoecol, 216: 183-188

Wignall P B, Newton R. 1998. Pyrite framboid diameter as a measure of oxygen deficiencyin ancient mudrocks. Am J Sci, 298: 537-552

Wilkin R T, Arthur M A, Dean W E. 1997b. History of water-column anoxia in the Black Sea indicated by pyrite framboid size distributions. Earth Planet Sci Lett, 148: 517-525

Wilkin R T, Arthur M A. 2001. Variations in pyrite texture, sulfur isotope composition, and iron systematics in the Black Sea, evidence for Late Pleistocene to Holocene excursionsof the $\mathrm{O}_{2}-\mathrm{H}_{2} \mathrm{~S}$ redox transition. Geochim Cosmochim Acta, 65: 1399-1416

Wilkin R T, Barnes H L, Brantley S L. 1996. The size distribution of framboidal pyrite: An indicator of redox conditions. Geochim Cosmochim Acta, 60: 3897-3912

Wilkin R T, Barnes H L. 1997a. Formation processes of framboidal pyrite. Geochim Cosmochim Acta, 61: 323-339

Xu G, Zhou J. 2001. The Xinqiao Cu-S-Fe-Au deposit in the Tongling mineral district, China: Synorogenic remobilization of a stratiform sulfide deposit. Ore Geol Rev, 18: 77-94

Yamaguchi S, Wada H. 1972. Greigite as seed for crystal growth of pyrrhotite. J Cry Grow, 15: 153-154

Zhou C M, Jiang S Y. 2009. Palaeoceanographic redox environments for the lower Cambrian Hetang formation in South China, evidence from pyrite framboids, redox sensitive trace elements, and sponge biota occurrence. Paleogeogr Paleoclimatol Paleoecol, 271: 279-286 